\title{
Ethno botanical Wisdom of Inhabitant of Devi Galli Azad Kashmir
}

\author{
Anam Shabir*, Naveed Iqbal Raja, Uneeza Javaid, Noor Ul Ain Zafar, Hina Javed and Farhat Yasmeen \\ Department of Botany, Faculty of Sciences Pir Mehr Ali Shah Arid Agriculture University, Pakistan
}

Received: September 22, 2017; Published: November 07, 2017

*Corresponding author: Anam Shabir, Department of Botany, Faculty of Sciences PirMehr Ali Shah Arid Agriculture University Rawalpindi Pakistan;

\begin{abstract}
Plants play vital role in our existence and are major substance of nutrition and medicament throughout the world. Plants are being used from early times to treat various human as well as animal's diseases. A series of survey were conducted to notice the highly remedial plants of Devi Galli Sudhnoti, Azad Jammu and Kashmir, Pakistan. Data was collected by direct comments during field studies, interviews and questionnaires from the local people. The locality, botanical, vernacular names, their family names and uses were elected. During study a total of 98 plants species related to 88 genera and 51 families were recorded. Most abundantly recorded families were Asteraceae, Poaceae, Moraceae, Convolvolaceae, Rosaceae, Fabaceae and Lamiaceae. Ethnobotanical uses classifications showed that major proportion was of medicinal plants species ( $85 \mathrm{spp}, 90.4 \%$ ) then fodder and forage species were (43 spp, 45.7\%) It is followed by other uses such as vegetables (13 spp, 13.8\%), fruit (19 spp, 20.2\%), Fuel (16 spp, 17\%) and timber species ( 5 spp, 5.3\%). Present survey has disclosed the ethno botanical importance of the plants and also suggested that there is dire need of conservation of these medicinally important plants for sustainable utilization as they are threatened by the loss of habitat and over exploitation.
\end{abstract}

Keywords: Devi Galli; Inhabitants; Flora; Ethnobotany

Abbreviations: FC: Frequency Citation; RFC: Relative Frequency Citation; UV: Use Value; FIV: Family importance value.

\section{Introduction}

Ethnobotany deals with study of the relationship between people of a specific culture and native plants and plays a significant role in understanding the active relations between social, traditional systems and biological diversity Husain et al. [1]; Mahmood et al.[2]. From many centuries and even today medicinal plants are used for dealing and prevention of various disorders and for the advancement of good health for people Alpuerto et al.[3]; Khatun et al. [4]. In Pakistan medicinal plants have been used as remedies for human diseases as well as for animal diseases for many centuries Haq [5]. Freshly collected ingredients from plants in small and massive quantities are used for ailments and also provided to the herbal industries through traded in the market place Uniyal et al. [6]. Hilly regions offer properties and services such as forests, agriculture foodstuffs, and water and biodiversity resources not only useable for local hilly area's people but also to a large part of the population living in plain areas Awan and Ahmad [7].

Azad Jammu and Kashmir (AJ\&K) is full of medicinal plants diversity. Many studies have been conducted on the uses of therapeutic plants by the indigenous populations of Azad Jammu and Kashmir Ishtiaq et al. [8]. District Sudhnoti is adjacent to Poonch division and situated at the height of $5400 \mathrm{ft}$. Most of areas of district Sudhnoti are out of the snow zone but some are in snow zone Khan et al. [9]. The flora of this district is also different from other districts. Vegetation of this district is patchy and dense with high alpine trees, whereas shrubs and small bushes are in large number. The World Health Organization (WHO) estimated that $80 \%$ of the population of developing countries relies on traditional medicines, mostly plant drugs, for their primary healthcare needs (WHO, 2017). Demand for medicinal plant is increasing in both developing and developed countries due to growing recognition of natural products, being non-narcotic, having no side-effects, easily available at affordable prices and sometime the only source of health care available to the poor Basha. The area is selected due to pronounced variety of medicinal plants but the region is still unexplored. The main objective was to document the knowledge of the local people of Devi Galli about the medicinal uses of local plants.

\section{Materials and Methods}

a) Study Area: The study area, District Sudhnoti is part of Division Poonch. Ethnobotanical study was limited to Devi Galli district (Sudhnoti) and some allied areas of district Sudhnoti 
Azad Kashmir. District Sudhnoti is spread over 569 sq. km and Devi Galli is a part of Sudhnoti Rafi et al. [10].

b) Field Trips: Field survey was consisting of plant collection, photography and data records. Semi-structured and open-ended interviews (questionnaire) were planned to gather ethnobotanical data. Interviews were taken general from native people of different age groups, shepherds and herbalists (Hakims) in their local language.

c) Plants Collection and Preservation: During various field surveys medicinally important plants were collected by keeping in view their utilization, flowering period and their products. These fully dehydrated samples were mounted on herbarium sheets and then noted their local name, botanical name, family, flower colour and locality. The plant species were recognized by plant taxonomists of UAAR and also used the Flora of Pakistan.

d) Quantitative Ethnobotanical Data Analysis: Indigenous knowledge was quantitatively calculated using various methods like Relative Frequency Citation (RFC), Use Value (UV) and Family Importance Value (FIV).

e) Relative Frequency Citation (RFC): Quantitative analysis of the collected ethno medicinal information was done Table 1: List of plants species with uses. by using a catalog of relative frequency citation (RFC) as; $\mathrm{RFC}=$ $\mathrm{FC} / \mathrm{N}(0<\mathrm{RFC}<1)$ This formula is given by the frequency of citation; FC that is the number of informants who mention the use of the species) while $\mathrm{N}$ is the total number of informants participating in the survey Vitalini et al.[11].

f) Use Value (UV): The Use Value (UV) is a good measure to all the possible uses of a plant species. UV gives us the virtual significance of a species that are cited by an informant for a specific species of medicinal plant. It will be intended by using the following given formula Savikin et al. [12].

$$
U V=\sum U i / N
$$

Where Ui is the number of uses revealed by each informer for a given species and $\mathrm{N}$ is the total number of informants.

g) Family importance value (FIV): Family importance value (FIV) was calculated by captivating the percentage of informants who mention the family Savikin.

$$
F I V=F C(\text { family }) / N \times 100
$$

Where (FC) is the number of informants who mention the family while $(\mathrm{N})$ is the total number of informants contributing in

\begin{tabular}{|c|c|c|c|c|c|c|}
\hline S.N. & plant Name & Common name & Family & Part used & Growth form & Ethnobotanical uses \\
\hline 1 & Achyranthus aspera Wall. & Puthkanda & Amaranthaceae & Whole plant & Herb & $\begin{array}{l}\text { The juiced of herb is given in diarrhoea and } \\
\text { skin diseases. Decoction is specified for } \\
\text { gastric problems. Foliage fixative is used } \\
\text { against insect bite. }\end{array}$ \\
\hline 2 & $\begin{array}{l}\text { Adiantum venustum D. } \\
\text { Don }\end{array}$ & Kakii & Adiantaceae & Leaves & Herb & $\begin{array}{l}\text { Leaves decoction is used to relief cold and } \\
\text { cough. Whole plant is also used as fodder. }\end{array}$ \\
\hline 3 & Acellia millefolium Linn. & Kangi & Asteraceae & Whole plant & Herb & $\begin{array}{l}\text { It is used to treat gum problem and mouth } \\
\text { soured. Liquid extract is used to remove } \\
\text { kidney stone. }\end{array}$ \\
\hline 4 & $\begin{array}{l}\text { Ailanthus altissima (P. } \\
\text { Mill) Swingle }\end{array}$ & Drave & Simaroubaceae & $S, L$ & Tree & $\begin{array}{l}\text { Plants stem (logs) and branches are used } \\
\text { for fuel and timber. }\end{array}$ \\
\hline 5 & Amaranthus spinosus L. & Ganar & Amaranthaceae & $\mathrm{W}$ & Herb & $\begin{array}{l}\text { Leaves are cooked as vegetable, effective } \\
\text { against constipation and obesity. Fodder for } \\
\text { cattle and goats. }\end{array}$ \\
\hline 6 & Anagallis arvensis $\mathrm{L}$. & $\begin{array}{l}\text { motkopra/bili } \\
\text { booti }\end{array}$ & Primulaceae & $\mathrm{W}$ & Herb & $\begin{array}{l}\text { Leaves and stem is cooked as vegetable that } \\
\text { have cooling effect on stomach. Entire plant } \\
\text { is used as food for animals. }\end{array}$ \\
\hline 7 & Arundo donax $\mathrm{L}$. & Naal & Poaceae & Whole plant & semi-shrub & $\begin{array}{l}\text { Decoction of leaves is given in cold and } \\
\text { cough. Plant is also used as food for animals. }\end{array}$ \\
\hline 8 & Artemisia vulgaris $\mathrm{L}$. & Chaoou & Asteraceae & $\mathrm{L}$ & Herb & $\begin{array}{l}\text { Fleshy leaves are cooked as vegetable. } \\
\text { Decoction is used for snake bite. }\end{array}$ \\
\hline 9 & Berrberis lycium Royle & Sumbal & Berrberidaceae & $\mathrm{W}$ & Shrub & $\begin{array}{l}\text { Root bark residue is used for wound healing } \\
\text { and its paste is used for join of fractured } \\
\text { bones. Roots extract has cooling effect and } \\
\text { is used to cure diabetes, boils and pimples } \\
\text { etc. Fruit is edible. Leaves are used as } \\
\text { fodder. Dry stem and branches are used as } \\
\text { fuel and also used to make fence. }\end{array}$ \\
\hline 10 & Bergenia ciliata Haw. & Bhatpahay & Saxifragraceae & $\mathrm{W}$ & Herb & $\begin{array}{l}\text { Plant leaves are used as fodder. Roots } \\
\text { powder is used for wound healing, diabetes } \\
\text { and skin diseases. }\end{array}$ \\
\hline 11 & $\begin{array}{c}\text { Broussonatia papyrifera } \\
\text { L. }\end{array}$ & Jangli toot & Moraceae & $\mathrm{L}, \mathrm{S}$ & Tree & $\begin{array}{l}\text { Plant stem is used as fuel and leaves as } \\
\text { fodder. }\end{array}$ \\
\hline
\end{tabular}
the study. 


\begin{tabular}{|c|c|c|c|c|c|c|}
\hline 12 & Canabis sativa Linn. & Bhang/ Phang & Cannabinaceae & $\mathrm{L}, \mathrm{I}$ & Shrub & $\begin{array}{l}\text { A leaf of cannabis and onion paste in the } \\
\text { form of poultice is applied on boils and } \\
\text { wounds. Crushed leaves and inflorenence } \\
\text { are use as drink to relief pain and having } \\
\text { sedative properties. }\end{array}$ \\
\hline 13 & $\begin{array}{l}\text { Capsella-bursa pastoris } \\
\text { (L.) Medik. }\end{array}$ & & Brassicaceae & $\mathrm{W}$ & Herb & $\begin{array}{l}\text { Most of the plant parts are used as fodder } \\
\text { for animals. }\end{array}$ \\
\hline 14 & $\begin{array}{c}\text { Commelina benghalensis } \\
\text { L. }\end{array}$ & Churra & Commelinaceae & $\mathrm{W}$ & Herb & $\begin{array}{l}\text { Plant is used as fodder, laxative and anti- } \\
\text { inflammatory use to treat animal diseases. }\end{array}$ \\
\hline 15 & Conyza canadensis L. & Paleet & Asteraceae & $\mathrm{W}$ & Herb & Whole plant is used as fodder and forage. \\
\hline 16 & Convolvulus arvensis $\mathrm{L}$. & Saanthe & Convolvolaceae & $\mathrm{W}$ & Herb & $\begin{array}{l}\text { Leaves are cocked as vegetable that are } \\
\text { effective against constipation. Whole plant } \\
\text { is used as fodder and forage. }\end{array}$ \\
\hline 17 & Chinopodium album L. & Karhan saag & Chenopodiaceae & $\mathrm{W}$ & Herb & $\begin{array}{l}\text { Plant leaves and stem is consumed as } \\
\text { fodder. }\end{array}$ \\
\hline 17 & Chichorium intybus $\mathrm{L}$. & $\begin{array}{c}\text { Kasni/ } \\
\text { Chichory/Hand }\end{array}$ & Asteraceae & $\mathrm{W}$ & Herb & $\begin{array}{l}\text { Cocked as vegetable effective against } \\
\text { constipation also used as fodder }\end{array}$ \\
\hline 19 & Cuscuta raflexa Roxb & Neela tari & Cuscutaceae & $\mathrm{W}$ & Climber & $\begin{array}{l}\text { Anti-lice, anti-anemia, antidandruff and } \\
\text { antipyretic. }\end{array}$ \\
\hline 20 & $\begin{array}{l}\text { Cuperssus sempervirens } \\
\text { L. }\end{array}$ & Sarroo & Cyperaceae & $\mathrm{W}$ & Shrub & It is an ornamental plant. \\
\hline 21 & Cynodon dactylon L. Pers & Khabal & Poaceae & $\mathrm{L}$ & Grass & $\begin{array}{l}\text { Paste of leaves is used to heal fractured } \\
\text { bones. Whole grass is used as Fodder. }\end{array}$ \\
\hline 22 & Cyperus rotundus $\mathrm{L}$. & Mutheer & Cyperaceae & $\mathrm{W}$ & $\begin{array}{l}\text { Perennial } \\
\text { herb }\end{array}$ & $\begin{array}{l}\text { Roots are Antipyretic, anti-inflammatory } \\
\text { and diuretic. Food for cattle. }\end{array}$ \\
\hline 23 & Dalbergia sissoo Roxb. & Tali & Fabaceae & L, S, B & & $\begin{array}{l}\text { Plant is used for fuel and fodder purposes. } \\
\text { Stem is used to make furniture. }\end{array}$ \\
\hline 23 & $\begin{array}{l}\text { Debergeasia longifolia } \\
\text { D. Don. }\end{array}$ & Sandari & Urticaeceae & F, L, S & Shrub & $\begin{array}{l}\text { Leaves used as fodder, branches and stem } \\
\text { for fuel, fruit is grind and used for bloody } \\
\text { diarrhea. }\end{array}$ \\
\hline 25 & $\begin{array}{l}\text { Digtaria senguinalis } \mathrm{L} . \\
\text { Scop. }\end{array}$ & Gaha & Poaceae & $\mathrm{L}$ & Grass & Plant is used as fodder and forage. \\
\hline 26 & $\begin{array}{l}\text { Dicliptera roxburgiana } \\
\text { Nees. }\end{array}$ & & Achanthaceae & $\mathrm{W}$ & Herb & $\begin{array}{l}\text { Plant is used as Fodder to avoid sun stroke } \\
\text { in buffaloes. }\end{array}$ \\
\hline 27 & Diosypros lotus $\mathrm{L}$. & Amlook & Ebenaceae & S, L, F & Tree & $\begin{array}{l}\text { Fruit is edible that is effective for stomach } \\
\text { troubles, leaves used as fodder for cattle } \\
\text { and dry wood is used for burning purpose. }\end{array}$ \\
\hline 28 & $\begin{array}{l}\text { Dryopteris ramosa (C. } \\
\text { Hope) C. Chr. }\end{array}$ & Langeri & Dryopteridaceae & $\mathrm{L}$ & Herb & $\begin{array}{l}\text { Leaves are cooked as vegetable that is very } \\
\text { delicious and also curative for constipation } \\
\text { and ulcer. }\end{array}$ \\
\hline 29 & $\begin{array}{l}\text { Ducesnia indica (Andr.) } \\
\text { Focke. }\end{array}$ & $\begin{array}{c}\text { Sapa na } \\
\text { amulbudha }\end{array}$ & Rosaceae & F, L & Herb & $\begin{array}{l}\text { Fruit is edible that is helpful to remove } \\
\text { kidney stone. Plant is also used as fodder. }\end{array}$ \\
\hline 30 & $\begin{array}{l}\text { Elaeagnus umbellata } \\
\text { (Wall.ex Royle) }\end{array}$ & Gayaani & Elaeagnaceae & $\mathrm{L}, \mathrm{S}, \mathrm{F}$ & Shrub & $\begin{array}{l}\text { Fruit is edible and used for cough and chest } \\
\text { pain, leaves used for fodder and stem and } \\
\text { twigs are used as fuel and to make fence. }\end{array}$ \\
\hline 31 & Euphorbia heliscpia L. & Doodal & Euphorbiaceae & $\mathrm{Sd}, \mathrm{R}, \mathrm{S}$ & Herb & $\begin{array}{l}\text { Small quantity is used to treat constipation } \\
\text { and cholera. }\end{array}$ \\
\hline 32 & Ficus palmata Forrsk & Phagwara & Moraceae & L, S, F, W & Tree & $\begin{array}{c}\text { Fruit is edible, laxative and good for } \\
\text { stomach. Leaves are cooked as vegetable } \\
\text { and also used as fodder for cattle and } \\
\text { goats. Wood of the plant is used as fuel. } \\
\text { Ash of leaves is consumed in Naswar (snuff } \\
\text { preparation). }\end{array}$ \\
\hline 33 & Fragaria vesca $\mathrm{L}$. & Ammal- budha & Rosaceae & W & Herb & $\begin{array}{l}\text { Fruit is edible used to treat stomach ulcer } \\
\text { with leaves of Berberis lycium. Leaves are } \\
\text { used to treat diarrhea in children. Whole } \\
\text { plant is used as fodder for goats. }\end{array}$ \\
\hline 34 & Gerenium wallichanum $\mathrm{L}$. & $\begin{array}{l}\text { Rati-boti/ } \\
\text { Ratan-jot }\end{array}$ & Gereniaceae & W & Herb & $\begin{array}{l}\text { Roots have cooling effects and used against } \\
\text { problems of urination. Leaves paste is used } \\
\text { for joints pain. }\end{array}$ \\
\hline
\end{tabular}




\begin{tabular}{|c|c|c|c|c|c|c|}
\hline 35 & $\begin{array}{l}\text { Geranium napalense } \\
\text { Sweet. }\end{array}$ & Jaree & Gereniaceae & $\mathrm{W}$ & Herb & \\
\hline 36 & $\begin{array}{l}\text { Gentiana olivieri } \\
\text { (Griseb.) Omer. }\end{array}$ & Nil-kanth & Gereniaceae & $\mathrm{W}$ & Herb & $\begin{array}{l}\text { Leaves boil in water and used for cough and } \\
\text { throat problems. }\end{array}$ \\
\hline 37 & $\begin{array}{l}\text { Grewia optiva Drum. Ex. } \\
\text { Burret }\end{array}$ & Thaman & Tiliaceae & $\mathrm{L}, \mathrm{S}$ & Shrub & $\begin{array}{l}\text { Leaves are used as food for animals and } \\
\text { are operative for delivery in cattle. Fruit is } \\
\text { edible. Baskets are made from branches } \\
\text { and twinges after soaking in water and } \\
\text { separated bark is also used to make ropes. }\end{array}$ \\
\hline 38 & Hedera helix $\mathrm{L}$. & Batkal & Araliaceae & L, S & Climber & $\begin{array}{l}\text { Leaves are used as fodder and forage and } \\
\text { powder of dry branches is used against } \\
\text { diabetes. }\end{array}$ \\
\hline 39 & Ipomea purpurea $\mathrm{L}$. & Aerh & Convolvolaceae & $\mathrm{W}$ & climber herb & $\begin{array}{l}\text { Plant is used as vegetable and leaves used } \\
\text { as fresh food for animals. }\end{array}$ \\
\hline 40 & $\begin{array}{l}\text { Indegofera heterantha } \\
\text { Wall }\end{array}$ & Manja/ Jand & Fabaceae & $S, L$ & Herb & $\begin{array}{l}\text { Twigs and bark is used to make ropes and } \\
\text { baskets. Leaves are used as fodder. }\end{array}$ \\
\hline 41 & Jasminum humile $\mathrm{L}$. & Chamba zard & Oleaceae & $S, R$ & Shrub & $\begin{array}{l}\text { Leaves decoction is used for curing } \\
\text { ringworms. It is cultivated as ornamental } \\
\text { plant. }\end{array}$ \\
\hline 42 & Juglans regia $\mathrm{L}$. & Akhor/ Akhrot & Juglandaceae & $\mathrm{S}, \mathrm{B}, \mathrm{F}$ & Tree & $\begin{array}{l}\text { Fruit is edible that is effective for heart } \\
\text { and brain. Stem bark is used as Miswak } \\
\text { (Toothbrush). Stem is used to make } \\
\text { furniture and also used as fuel. }\end{array}$ \\
\hline 43 & Lathyrus ophaca L. & Jngli phalli & Fabaceae & $\mathrm{W}$ & Herb & $\begin{array}{l}\text { Whole plant is used as fodder. Fruit is } \\
\text { edible. }\end{array}$ \\
\hline 44 & Melia azedrach L. & Dhark & Meliaceae & L, S & Shrub & $\begin{array}{l}\text { Leaves extract is used to cure r skin } \\
\text { diseases. Stem and branches are used as } \\
\text { fuel. }\end{array}$ \\
\hline 45 & Mentha longifolia L. & Chata podina & Lamiaceae & $\mathrm{L}$ & Herb & $\begin{array}{l}\text { This plant has cooling effects. Dried leaves } \\
\text { are orally taken that are carminative. } \\
\text { Mentha leaves, seeds of punica and green } \\
\text { chilies are used to make chatni }\end{array}$ \\
\hline 46 & Mentha arvensis $\mathrm{L}$. & Kala podina & Lamiaceae & $\mathrm{L}$ & Herb & $\begin{array}{l}\text {. Leaves are used to make chatni that is } \\
\text { Carminative and cooling effects for digestive } \\
\text { system }\end{array}$ \\
\hline 47 & Melilotus indica L. All. & Sereey & Fabaceae & $\mathrm{L}$ & Herb & $\begin{array}{l}\text { Leaves are cooked as vegetable (sag). Plant } \\
\text { is used as fodder. }\end{array}$ \\
\hline 48 & Medicago polymorpha L. & Maina & Fabaceae & $\mathrm{W}$ & Herb & Plant is used as fodder. \\
\hline 49 & Morus nigra L. & Kala toot & Moraceae & $F, L, S$ & Herb & $\begin{array}{l}\text { Fresh leaves are used as fodder. Fruit is } \\
\text { edible, effective for constipation. Wood } \\
\text { is used for fuel and also used to make } \\
\text { furniture. }\end{array}$ \\
\hline 50 & $\begin{array}{l}\text { Nasturtium officinale } \\
\text { R. Br. }\end{array}$ & Chaoo & Brassicaceae & $\mathrm{W}$ & Herb & $\begin{array}{l}\text { Leaves are cooked as vegetable that is } \\
\text { carminative. }\end{array}$ \\
\hline 51 & Oenothera rosea (L.) & Jangli nashtar & Onagaraceae & $\mathrm{W}$ & Herb & Plant is used as fodder. \\
\hline 52 & Oxalis corniculata (L.) & $\begin{array}{l}\text { Khatola/ } \\
\text { Khatimethi }\end{array}$ & Oxalidaceae & $\mathrm{W}$ & Herb & $\begin{array}{l}\text { Leaves extract is used for juindance also } \\
\text { cooked as vegetable that is antipyretic. } \\
\text { Whole plant is used as fodder. }\end{array}$ \\
\hline 53 & $\begin{array}{l}\text { Pennisetum orientale } \\
\text { Rich. }\end{array}$ & Siliak gaha & Poaceae & $\mathrm{W}$ & Grass & Plant is used as fodder. \\
\hline 54 & $\begin{array}{l}\text { Pinus roxburghii } \\
\text { (Sergent) }\end{array}$ & Chir & Pinaceae & $\mathrm{L}, \mathrm{S}, \mathrm{Sd}$ & Tree & $\begin{array}{l}\text { Tuberculosis patient are advised to sit } \\
\text { under the shade of the chir (tree) for } \\
\text { recovery. Wood is used as timber and also } \\
\text { for fuel. Seed are edible and nutritional. } \\
\text { Stem logs and dried leaves are used for roof } \\
\text { thatching. Heart wood used for ignition } \\
\text { purposes. }\end{array}$ \\
\hline 55 & $\begin{array}{l}\text { Pinus wallichiana } \\
\text { (Jackson) }\end{array}$ & Rarar & Pinaceae & S, L, & Tree & $\begin{array}{l}\text { Stem is used for constriction purposes. } \\
\text { Branches are used for fuel and roof } \\
\text { thatching. Leaves are used for ignition } \\
\text { purpose. }\end{array}$ \\
\hline
\end{tabular}




\begin{tabular}{|c|c|c|c|c|c|c|}
\hline 56 & Plantago lanceolata $\mathrm{L}$. & Salathee & Plantaganaceae & $\mathrm{W}$ & Herb & $\begin{array}{l}\text { Plant is used as fodder. Leaves have } \\
\text { wound healing characters and seed or } \\
\text { inflorescence is used against constipation. }\end{array}$ \\
\hline 57 & Plantago major L. & $\begin{array}{l}\text { Salathee/ } \\
\text { ispghol }\end{array}$ & Plantaganaceae & W & Herb & $\begin{array}{l}\text { Leaves decoction is used for cough, } \\
\text { cholesterol level and constipation. Whole } \\
\text { Plant is used as fodder. }\end{array}$ \\
\hline 58 & $\begin{array}{l}\text { Populus deletoides Bart. } \\
\text { Ex. Marsh }\end{array}$ & Safada & Salicaceae & S, L, & Tree & $\begin{array}{l}\text { Plant stem and branches are used for } \\
\text { sheltering and as a fuel. Branches with } \\
\text { leaves for shade. }\end{array}$ \\
\hline 59 & Poa anпиа $\mathrm{L}$. & Malla & Poaceae & $\mathrm{L}$ & Grass & Plant is used as fodder. \\
\hline 60 & $\begin{array}{l}\text { Prunus persica (L.) } \\
\text { Bastch. }\end{array}$ & Arwari & Rosaceae & $\mathrm{F}, \mathrm{S}, \mathrm{L}$ & Tree & $\begin{array}{l}\text { Leaves are used as fodder. Fruit is laxative } \\
\text { and good for stomach, antipyretic and } \\
\text { germs killing. Stem and branches are used } \\
\text { as fuel. }\end{array}$ \\
\hline 61 & $\begin{array}{l}\text { Prunus bokharensis } \\
\text { (Royle) }\end{array}$ & Alobakhary & Rosaceae & $\mathrm{F}, \mathrm{S}, \mathrm{L}$ & Tree & $\begin{array}{l}\text { Plant leaves are used as fodder. Fruit is } \\
\text { purgative and digestive. Leaves and bark } \\
\text { paste is used for wound healing. Dry wood } \\
\text { is used for burning purposes. }\end{array}$ \\
\hline 62 & Pteris cretica $\mathrm{L}$. & Koochan & Petridaceae & $\mathrm{L}$ & Tree & $\begin{array}{l}\text { Paste of leaves in water is prepared that is } \\
\text { placed in cloth and applied on wound for } \\
\text { quick healing. }\end{array}$ \\
\hline 63 & Punica granatum L. & Daroni/ Darona & Punicaeae & F, S, Sd & Shrub & $\begin{array}{l}\text { Dried fruit (Anardana) used as condiment. } \\
\text { Chatni is prepared by seeds of punica, } \\
\text { mentha leaves and green chilies that is } \\
\text { carminative and has cooling effects. }\end{array}$ \\
\hline 64 & Pyrus pashia Buch. & Tangi/ Batangi & Rosaceae & $\mathrm{F}, \mathrm{S}, \mathrm{L}$ & Tree & $\begin{array}{l}\text { Fruit is edible that is good for stomach. } \\
\text { Leaves are used as food for animals. Dry } \\
\text { stem and twigs wood is used as fuel. }\end{array}$ \\
\hline 65 & Quercus incana Roxb. & Rein/ Erroo & Fagaceae & L, S, B & Semi-Tree & $\begin{array}{l}\text { Leaves used as fodder for cattle. Stem and } \\
\text { branches used as fuel. Decoction of bark is } \\
\text { effective against joints pain. }\end{array}$ \\
\hline 66 & Rannunculus laetus $\mathrm{L}$. & Meleeth & Ranunculaceae & $\mathrm{W}$ & Herb & Plant is used as fodder for cattle. \\
\hline 67 & $\begin{array}{l}\text { Rannunculus arvensis } \\
\text { Linn. }\end{array}$ & Chochomba & Ranunculaceae & $\mathrm{L}, \mathrm{S}$ & Herb/Weed & $\begin{array}{l}\text { Plant is used as fodder and cooked as } \\
\text { vegetable. }\end{array}$ \\
\hline 68 & Rosa brunonii (Lindl) & Tarnal & Rosaceae & $\mathrm{L}, \mathrm{F}$ & Shrub & $\begin{array}{l}\text { Leaves used as fodder. Flower is used } \\
\text { against scabies, heart and digestive } \\
\text { problems. }\end{array}$ \\
\hline 69 & Robinia pseudoacaceia L. & Keekar & Fabaceae & S, L, & Shrub & $\begin{array}{l}\text { Stem and twigs are available for fuel and } \\
\text { fencing. Whole plant is used for shade. }\end{array}$ \\
\hline 70 & $\begin{array}{l}\text { Rubia manjith Roxb. Ex } \\
\text { flaming }\end{array}$ & & Rubiacaeae & $\mathrm{R}$ & Herb & Extract of root is effective in discomfort. \\
\hline 71 & Rubus elipticus Smith. & Akharay & Rosaceae & $\mathrm{F}, \mathrm{S}, \mathrm{L}$ & Shrub & $\begin{array}{l}\text { Only leaves of plants are used as fodder. } \\
\text { Fruit remains edible and stem and branches } \\
\text { are used for fencing. }\end{array}$ \\
\hline 72 & Rubus fruticosus Wallich & Pamnaar & Rosaceae & $\mathrm{F}, \mathrm{S}, \mathrm{L}$ & Shrub & $\begin{array}{l}\text { Twigs are used for paling. Leaves as fodder } \\
\text { and fruit are comestible and having chilling } \\
\text { effect. }\end{array}$ \\
\hline 73 & Rumex hastatus D. Don & Chukhreey & Polygonaceae & $\mathrm{L}, \mathrm{R}$ & $\begin{array}{l}\text { Perennial } \\
\text { herb }\end{array}$ & $\begin{array}{l}\text { Plant is a source of food for animals. Foliage } \\
\text { paste is used to stop bleeding from wounds. } \\
\text { Cocked as vegetable that is effective } \\
\text { against juindance and reaction of different } \\
\text { medicines. }\end{array}$ \\
\hline 74 & Rumex nepelensis D. Don & $\begin{array}{l}\text { Halfree/ Jangli } \\
\text { palak }\end{array}$ & Polygonaceae & $\mathrm{L}$ & Herb & $\begin{array}{l}\text { Effective against the irritation caused by } \\
\text { urtica dioica. Leaves extract is used against } \\
\text { wounds. }\end{array}$ \\
\hline 75 & $\begin{array}{c}\text { Saccharum spontaneum } \\
\text { L. }\end{array}$ & Kai & Poaceae & $\mathrm{W}$ & Grass & Whole plant is used as fodder and forage. \\
\hline 76 & $\begin{array}{l}\text { Sarcococca saligna (D. } \\
\text { Don) Muel }\end{array}$ & Ndroon & Buxaceae & $S, L$ & Shrub & $\begin{array}{l}\text { Stem and branches are used for roof } \\
\text { thatching. Leaves are antipyretic. }\end{array}$ \\
\hline 77 & $\begin{array}{l}\text { Setaria viridis (L.) P. } \\
\text { Beauv. }\end{array}$ & $\begin{array}{l}\text { Soonkh gaha/ } \\
\text { Jeshay }\end{array}$ & Poaceae & $\mathrm{L}$ & Grass & Plant provide source of food for animals. \\
\hline
\end{tabular}




\begin{tabular}{|c|c|c|c|c|c|c|}
\hline 78 & Salix alba Linn. & Beesa & Salicaceae & $S, R$ & Tree & $\begin{array}{l}\text { Dried branches and stem is used for fuel } \\
\text { and for furniture making, cricket bats. }\end{array}$ \\
\hline 79 & Solanum villosum $\mathrm{L}$. & Kachmach & Solanaceae & $\mathrm{L}, \mathrm{F}$ & Herb & $\begin{array}{l}\text { Fruit is edible and effective for mouth sores. } \\
\text { Leaves and fruit is cooked as vegetable and } \\
\text { used to treat stomachache. }\end{array}$ \\
\hline 80 & $\begin{array}{c}\text { Solanum pseudocasicum } \\
\text { L. }\end{array}$ & Merchooli & Solanaceae & $\mathrm{F}$ & Herb & $\begin{array}{l}\text { Excess of fruit use cause vomiting and } \\
\text { become poison. Leaves are used to treat } \\
\text { boils. }\end{array}$ \\
\hline 81 & Sonchus arvense L. & Hand & Asteraceae & $\mathrm{W}$ & Herb & $\begin{array}{l}\text { Cooked as vegetable that is anti-diabetic. } \\
\text { Food for cattle and goats. }\end{array}$ \\
\hline 82 & Stelaria media L. & Ladroo & Caryophyllaceae & $\mathrm{W}$ & Herb & $\begin{array}{l}\text { Plant is used as vegetable which be there } \\
\text { effective for period's discomfort. }\end{array}$ \\
\hline 83 & $\begin{array}{l}\text { Stobilanthes attenuata } \\
\text { Nees }\end{array}$ & Melool & Achanthaceae & $\mathrm{W}$ & Herb & It is an ornamental plant. \\
\hline 84 & Sorghum halepense Pers. & Baru gaha & Poaceae & $\mathrm{W}$ & Grass & Plant is used as fodder \\
\hline 85 & Swertia chirata Wall. & Chariata & Gentianaceae & $\mathrm{L}$ & Herb & $\begin{array}{l}\text { Plant foliage is grinded in water and that } \\
\text { abstract is good against fever in malaria. }\end{array}$ \\
\hline 86 & $\begin{array}{l}\text { Taraxicum officinale } \\
\text { (Weber) }\end{array}$ & Kali hand & Asteraceae & L, R, Sd & Herb & $\begin{array}{l}\text { Cooked as vegetable which is diuretic, } \\
\text { antidiabetic and used to cure jaundice. }\end{array}$ \\
\hline 87 & Tagetes minuta $\mathrm{L}$. & Sat barga & Asteraceae & $\mathrm{F}$ & Shrub & Ornamental plant. \\
\hline 88 & Tagetes patula $\mathrm{L}$. & Sat barga & Asteraceae & $\mathrm{F}$ & Shrub & Ornamental plant. \\
\hline 89 & $\begin{array}{c}\text { Themeda } \\
\text { anathera(Hack) }\end{array}$ & Bari ghas & Poaceae & $\mathrm{W}$ & Grass & Plant is be there as fodder. \\
\hline 90 & Trifolium repense $\mathrm{L}$. & Shtall & Fabaceae & $\mathrm{W}$ & Herb & $\begin{array}{l}\text { Gout problem is treated through leaves. } \\
\text { Plant leaves are used as fodder for animals. }\end{array}$ \\
\hline 91 & $\begin{array}{l}\text { Ulmus wallichiana } \\
\text { Planch. Subsp. }\end{array}$ & Mannu & Ulmaceae & $\mathrm{L}, \mathrm{S}$ & Tree & $\begin{array}{l}\text { Leaves are used as fodder. Stem is used to } \\
\text { make furniture also used for fuel. }\end{array}$ \\
\hline 92 & Verbena officinale $\mathrm{L}$. & Chroonoon & Verbenaceae & $\mathrm{W}$ & Herb & $\begin{array}{l}\text { Plant is used as fodder. Leaves paste is good } \\
\text { for headache and joints pain }\end{array}$ \\
\hline 93 & Verbescum thapsus Linn. & Kakar tambaco & Verbenaceae & $\mathrm{L}$ & Herb & $\begin{array}{l}\text { Leaves juice is used to treat earache. Dried } \\
\text { leaves are smoked to remove asthma and } \\
\text { cough. }\end{array}$ \\
\hline 94 & Viola odorata Linn. & Gul-naksha & Violaceae & $\mathrm{W}$ & Herb & $\begin{array}{l}\text { Leaves extract or infusion is used to cure } \\
\text { typhoid fever. Leaves or flower are used to } \\
\text { cure respiratory problems. }\end{array}$ \\
\hline 95 & $\begin{array}{l}\text { Viburnum grandiflorum } \\
\text { Wall. Ex DC. }\end{array}$ & Jammar & Caprifoliaceae & $\mathrm{S}, \mathrm{F}$ & Shrub & $\begin{array}{l}\text { Fruit is edible that is effective to cure } \\
\text { cough. Stem is soaked in water and used } \\
\text { to make baskets. Stem is also used to make } \\
\text { toothbrush (Miswak). }\end{array}$ \\
\hline 96 & Vitis vinifera Linn. & Dakh & Vitaceae & $\mathrm{L}, \mathrm{F}$ & Climber/Herb & $\begin{array}{l}\text { Fruit juice is used to cure fever. Leaves are } \\
\text { used as fodder. }\end{array}$ \\
\hline 97 & Xanthium stromarium L. & Kanda & Asteraceae & S & Shrub & Seed poultice is applied on wounds. \\
\hline 98 & $\begin{array}{l}\text { Zanthoxylum armatum } \\
\text { DC. }\end{array}$ & Timber & Rutaceae & S, L, Sd & Shrub & $\begin{array}{l}\text { Seed are used to make "Chatni" that is } \\
\text { carminative. Leaves are used as fodder } \\
\text { by animals. Dried twigs are used to make } \\
\text { walking sticks and handle of different } \\
\text { instruments. Young branches are used to } \\
\text { make toothbrush. }\end{array}$ \\
\hline
\end{tabular}

Table 2: Use Value, Frequency Citation and Relative Frequency Citation of plants.

\begin{tabular}{|c|c|c|c|c|c|c|}
\hline S.N & plant Name & Common name & Family & FC & RFC & UV \\
\hline 1 & Achyranthus aspera Wall. & Puthkanda & Amaranthaceae & 4 & 0.03 & 0.04 \\
\hline 2 & Adiantum venustum D. Don & Kakii & Adiantaceae & 3 & 0.02 & 0.03 \\
\hline 3 & Acellia millefolium Linn. & Kangi & Asteraceae & 5 & 0.04 & 0.02 \\
\hline 4 & Ailanthus altissima (P. Mill) Swingle & Drave & Simaroubaceae & 7 & 0.05 & 0.03 \\
\hline 5 & Amaranthus spinosus $L$. & Ganar & Amaranthaceae & 6 & 0.04 & 0.10 \\
\hline 6 & Anagallis arvensis L. & motkopra/bili booti & Primulaceae & 73 & 0.54 & 0.93 \\
\hline
\end{tabular}




\begin{tabular}{|c|c|c|c|c|c|c|}
\hline 7 & Arundo donax $L$. & Naal & Poaceae & 2 & 0.01 & 0.04 \\
\hline 8 & Artemisia vulgaris $L$. & Chaoou & Asteraceae & 4 & 0.03 & 0.04 \\
\hline 9 & Berrberis lycium Royle & Sumbal & Berrberidaceae & 5 & 0.04 & 0.13 \\
\hline 10 & Bergenia ciliata Haw. & Bhatpahay & Saxifragraceae & 1 & 0.01 & 0.01 \\
\hline 11 & Broussonatia papyrifera $L$. & Jangli toot & Moraceae & 6 & 0.04 & 0.07 \\
\hline 12 & Canabis sativa Linn. & Bhang/ Phang & Cannabinaceae & 4 & 0.02 & 0.04 \\
\hline 13 & Capsella-bursa pastoris (L.) Medik. & Jari & Brassicaceae & 2 & 0.01 & 0.01 \\
\hline 14 & Commelina benghalensis $L$. & Churra & Commelinaceae & 28 & 0.21 & 0.16 \\
\hline 15 & Conyza canadensis $L$. & Paleet & Asteraceae & 5 & 0.04 & 0.04 \\
\hline 16 & Convolvulus arvensis $L$. & Saanthe & Convolvolaceae & 4 & 0.02 & 0.05 \\
\hline 17 & Chinopodium album $L$. & Karhan saag & Chenopodiaceae & 2 & 0.01 & 0.01 \\
\hline 17 & Chichorium intybus $L$. & Kasni/Chichory/Hand & Asteraceae & 9 & 0.67 & 0.09 \\
\hline 19 & Cuscuta raflexa Roxb & Neela tari & Cuscutaceae & 11 & 0.08 & 0.06 \\
\hline 20 & Cuperssus sempervirens $L$. & Sarroo & Cyperaceae & 25 & 0.19 & 0.11 \\
\hline 21 & Cynodon dactylon L. Pers & Khabal & Poaceae & 45 & 0.33 & 0.13 \\
\hline 22 & Cyperus rotundus $L$. & Mutheer & Cyperaceae & 4 & 0.03 & 0.04 \\
\hline 23 & Dalbergia sissoo Roxb. & Tali & Fabaceae & 15 & 0.11 & 0.10 \\
\hline 23 & Debergeasia longifolia D. Don. & Sandari & Urticaeceae & 20 & 0.15 & 0.12 \\
\hline 25 & Digtaria senguinalis L. Scop. & Gaha & Poaceae & 60 & 0.44 & 0.38 \\
\hline 26 & Dicliptera roxburgiana Nees. & & Achanthaceae & 1 & 0.01 & 0.01 \\
\hline 27 & Diosypros lotus $L$. & Amlook & Ebenaceae & 16 & 0.12 & 0.11 \\
\hline 28 & Dryopteris ramosa (C. Hope) C. Chr. & Langeri & Dryopteridaceae & 2 & 0.01 & 0.04 \\
\hline 29 & Ducesnia indica (Andr.) Focke. & Sapa na amulbudha & Rosaceae & 3 & 0.02 & 0.05 \\
\hline 30 & Elaeagnus umbellata (Wall.ex Royle) & Gayaani & Elaeagnaceae & 35 & 0.26 & 0.18 \\
\hline 31 & Euphorbia heliscpia L. & Doodal & Euphorbiaceae & 1 & 0.01 & 0.01 \\
\hline 32 & Ficus palmata Forrsk & Phagwara & Moraceae & 30 & 0.22 & 0.19 \\
\hline 33 & Fragaria vesca $L$. & Ammal- budha & Rosaceae & 13 & 0.10 & 0.13 \\
\hline 34 & Gerenium wallichanum $L$. & Rati-boti/ Ratan-jot & Gereniaceae & 4 & 0.03 & 0.04 \\
\hline 35 & Geranium napalense Sweet. & & Gereniaceae & 3 & 0.02 & 0.02 \\
\hline 36 & Gentiana olivieri (Griseb.) Omer. & Nil-kanth & Gereniaceae & 10 & 0.07 & 0.05 \\
\hline 37 & Grewia optiva Drum. Ex. Burret & Thaman & Tiliaceae & 6 & 0.04 & 0.13 \\
\hline 38 & Hedera helix L. & Batkal & Araliaceae & 2 & 0.01 & 0.03 \\
\hline 39 & Ipomea purpurea L. & Aerh & Convolvolaceae & 50 & 0.37 & 0.51 \\
\hline 40 & Indegofera heterantha Wall & Manja/ Jand & Fabaceae & 8 & 0.06 & 0.07 \\
\hline 41 & Jasminum humile L. & Chamba zard & Oleaceae & 2 & 0.01 & 0.04 \\
\hline 42 & Juglans regia $L$. & Akhor/ Akhrot & Juglandaceae & 18 & 0.13 & 0.22 \\
\hline 43 & Lathyrus ophaca L. & Jngli phalli & Fabaceae & 4 & 0.03 & 0.06 \\
\hline 44 & Melia azedrach L. & Dhark & Meliaceae & 73 & 0.54 & 0.60 \\
\hline 45 & Mentha longifolia L. & Chata podina & Lamiaceae & 95 & 0.70 & 0.82 \\
\hline 46 & Mentha arvensis $L$. & Kala podina & Lamiaceae & 100 & 0.74 & 0.82 \\
\hline 47 & Melilotus indica L. All. & Sereey & Fabaceae & 63 & 0.46 & 0.38 \\
\hline 48 & Medicago polymorpha L. & Maina & Fabaceae & 14 & 0.10 & 0.09 \\
\hline 49 & Morus nigra L. & Kala toot & Moraceae & 36 & 0.26 & 0.67 \\
\hline 50 & Nasturtium officinale R. Br. & Chaoo & Brassicaceae & 28 & 0.20 & 0.01 \\
\hline 51 & Oenothera rosea (L.) & Jangli nashtar & Onagaraceae & 4 & 0.03 & 0.01 \\
\hline 52 & Oxalis corniculata $(L)$. & Khatola/Khatimethi & Oxalidaceae & 80 & 0.59 & 0.02 \\
\hline 53 & Pennisetum orientale Rich. & Siliak gaha & Poaceae & 38 & 0.28 & 0.01 \\
\hline 54 & Pinus roxburghii (Sergent) & Chir & Pinaceae & 45 & 0.33 & 0.04 \\
\hline
\end{tabular}




\begin{tabular}{|c|c|c|c|c|c|c|}
\hline 55 & Pinus wallichiana (Jackson) & Rarar & Pinaceae & 80 & 0.60 & 0.03 \\
\hline 56 & Plantago lanceolata $L$. & Salathee & Plantaganaceae & 6 & 0.04 & 0.01 \\
\hline 57 & Plantago major $L$. & Salathee/ ispghol & Plantaganaceae & 3 & 0.02 & 0.00 \\
\hline 58 & Populus deletoides Bart. Ex. Marsh & Safada & Salicaceae & 13 & 0.10 & 0.02 \\
\hline 59 & Poa annua $L$. & Malla & Poaceae & 26 & 0.19 & 0.01 \\
\hline 60 & Prunus persica (L.) Bastch. & Arwari & Rosaceae & 18 & 0.13 & 0.28 \\
\hline 61 & Prunus bokharensis (Royle) & Alobakhary & Rosaceae & 48 & 0.36 & 0.71 \\
\hline 62 & Pteris cretica $L$. & Koochan & Petridaceae & 2 & 0.01 & 0.02 \\
\hline 63 & Punica granatum $L$. & Daroni/ Darona & Punicaeae & 56 & 0.41 & 0.50 \\
\hline 64 & Pyrus pashia Buch. & Tangi/ Batangi & Rosaceae & 15 & 0.11 & 0.34 \\
\hline 65 & Quercus incana Roxb. & Rein/ Erroo & Fagaceae & 12 & 0.09 & 0.16 \\
\hline 66 & Rannunculus laetus $L$. & Meleeth & Ranunculaceae & 2 & 0.01 & 0.01 \\
\hline 67 & Rannunculus arvensis Linn. & Chochomba & Ranunculaceae & 4 & 0.03 & 0.04 \\
\hline 68 & Rosa brunonii (Lindl) & Tarnal & Rosaceae & 9 & 0.07 & 0.08 \\
\hline 69 & Robinia pseudoacaceia L. & Keekar & Fabaceae & 23 & 0.17 & 0.20 \\
\hline 70 & Rubia manjith Roxb. Ex flaming & & Rubiacaeae & 4 & 0.03 & 0.02 \\
\hline 71 & Rubus elipticus Smith. & Akharay & Rosaceae & 16 & 0.11 & 0.22 \\
\hline 72 & Rubus fruticosus Wallich & Pamnaar & Rosaceae & 17 & 0.13 & 0.07 \\
\hline 73 & Rumex hastatus D. Don & Chukhreey & Polygonaceae & 5 & 0.04 & 0.05 \\
\hline 74 & Rumex nepelensis D. Don & Halfree/ Jangli palak & Polygonaceae & 5 & 0.04 & 0.07 \\
\hline 75 & Saccharum spontaneum $L$. & Kai & Poaceae & 46 & 0.34 & 0.30 \\
\hline 76 & Sarcococca saligna (D. Don) Muel & Ndroon & Buxaceae & 2 & 0.01 & 0.02 \\
\hline 77 & Setaria viridis (L.) P. Beauv. & Soonkh gaha/Jeshay & Poaceae & 26 & 0.19 & 0.18 \\
\hline 78 & Salix alba Linn. & Beesa & Salicaceae & 7 & 0.05 & 0.11 \\
\hline 79 & Solanum villosum $L$. & Kachmach & Solanaceae & 67 & 0.50 & 0.48 \\
\hline 80 & Solanum pseudocasicum $L$. & Merchooli & Solanaceae & 3 & 0.02 & 0.01 \\
\hline 81 & Sonchus arvense $L$. & Hand & Asteraceae & 33 & 0.24 & 0.56 \\
\hline 82 & Stelaria media $L$. & Ladroo & Caryophyllaceae & 19 & 0.14 & 0.10 \\
\hline 83 & Stobilanthes attenuata Nees & Melool & Achanthaceae & 1 & 0.01 & 0.01 \\
\hline 84 & Sorghum halepense Pers. & Baru gaha & Poaceae & 91 & 0.07 & 0.65 \\
\hline 85 & Swertia chirata Wall. & Chariata & Gentianaceae & 25 & 0.19 & 0.19 \\
\hline 86 & Taraxicum officinale (Weber) & Kali hand & Asteraceae & 19 & 0.14 & 0.26 \\
\hline 87 & Tagetes minuta L. & Sat barga & Asteraceae & 3 & 0.02 & 0.01 \\
\hline 88 & Tagetes patula $L$. & Sat barga & Asteraceae & 5 & 0.04 & 0.01 \\
\hline 89 & Themeda anathera(Hack) & Bari ghas & Poaceae & 14 & 0.10 & 0.08 \\
\hline 90 & Trifolium repense $L$. & Shtall & Fabaceae & 4 & 0.03 & 0.04 \\
\hline 91 & Ulmus wallichiana Planch. Subsp. & Mannu & Ulmaceae & 11 & 0.08 & 0.17 \\
\hline 92 & Verbena officinale $L$. & Chroonoon & Verbenaceae & 2 & 0.01 & 0.04 \\
\hline 93 & Verbescum thapsus Linn. & Kakar tambaco & Verbenaceae & 21 & 0.16 & 0.14 \\
\hline 94 & Viola odorata Linn. & Gul-naksha & Violaceae & 87 & 0.64 & 0.59 \\
\hline 95 & Viburnum grandiflorum Wall. Ex DC. & Jammar & Caprifoliaceae & 10 & 0.07 & 0.21 \\
\hline 96 & Vitis vinifera Linn. & Dakh & Vitaceae & 5 & 0.04 & 0.10 \\
\hline 97 & Xanthium stromarium $L$. & Kanda & Asteraceae & 2 & 0.01 & 0.01 \\
\hline 98 & Zanthoxylum armatum DC. & Timber & Rutaceae & 56 & 0.41 & 0.51 \\
\hline
\end{tabular}

\section{Results and Discussion}

\section{Vegetation records and ethno-demography data}

During Ethnobotanical study, a total of 98 plant species related to 88 genera and 51 different families are documented. Most of these species are used by native individuals for a multiplicity of purposes. (Table 1) contains botanical, local names, family name and folkloric uses, (Table 2) represent FC, RFC and UV of different plants. A total of 135 participants were interviewed out of which 46 were male and 89 were females of different age group. Majority of 
people were uneducated 97 were married and 31 unmarried only 6 were herbalist and 129 were local people.

Most abundantly recorded families were Asteraceae, Poaceae, Moraceae, Convolvolaceae, Rosaceae, Fabaceae and Lamiaceae. Ethnobotanical uses classifications showed that major proportion of medicinal plants species was (85 spp, 90.4\%) then fodder and forage species were (43 spp, 45.7\%) It is followed by other uses such as vegetables (13 spp, 13.8\%), fruit (19 spp, 20.2\%), Fuel (16 spp, 17\%) and timber species (5 spp, 5.3\%).

\section{Relative Frequency Citation (RFC)}

Relative frequency citation was considered to record maximum therapeutic flora of the area which is utilized for treatment of various ailments. It gives the number of informers who mention the uses of plants. Most cited plants were Mentha arvensis L. (0.74), Chichorium intybus L. (0.66), Anagallis arvensis L (0.54), Oxalis corniculata (L.) (0.59), Melia azedrach L (0.54), Digtaria senguinalis L. Scop (0.44), Viola odorata Linn. (0.64).

\section{Use Value (UV)}

The use value (UV) is technique for measurable analysis of data it gives the important uses of species. Some of plants were recorded with high UV that are Anagallis arvensis L. (0.92), Mentha longifolia L. (0.82), Mentha arvensis L. (0.82), Prunus bokharensis (Royle) (0.71), Morus nigra L. (0.67), Sorghum halepense Pers. (0.65), Melia azedrach L. (0.6), Viola odorata Linn. (0.59), Zanthoxylum armatum DC. (0.51), Punica granatum L. (0.50), Pyrus pashia Buch. (0.34), Taraxicum officinale (Weber) (0.26), Rubus elipticus Smith. (0.22) etc.

Figure 1: Families.

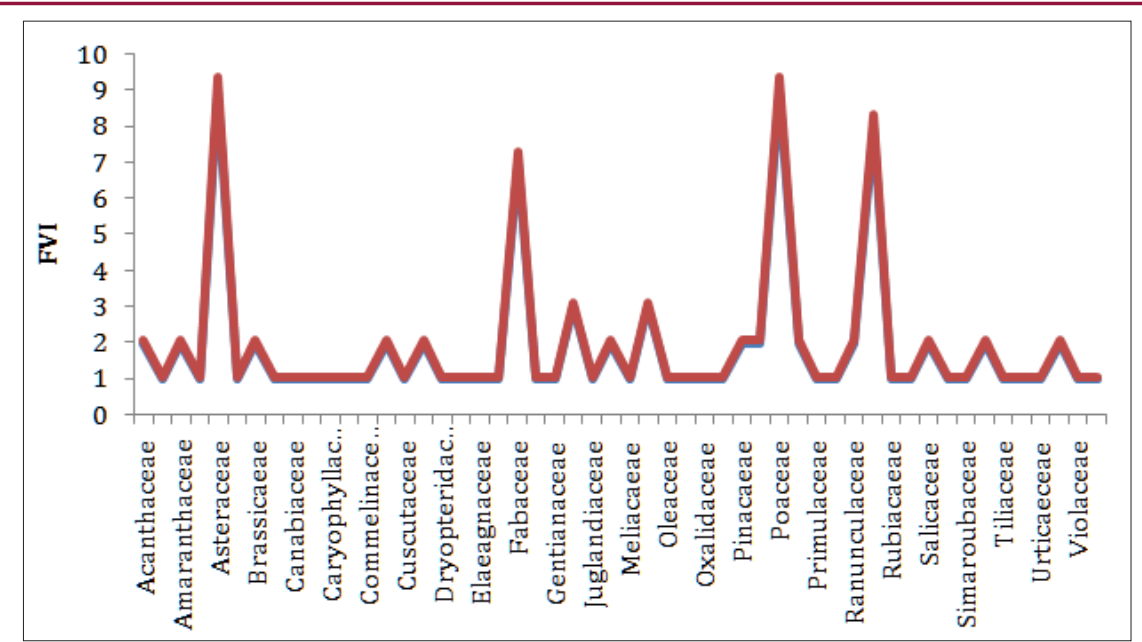

\section{Family Importance Value (FIV)}

Family importance value is calculated and described in the form of graph in Figures 1,2. Amaranthaceae, Asteraceae, Poaceae, Moraceae, Convolvolaceae, Rosaceae, Fabaceae and Lamiaceae were most abundantly reported families.

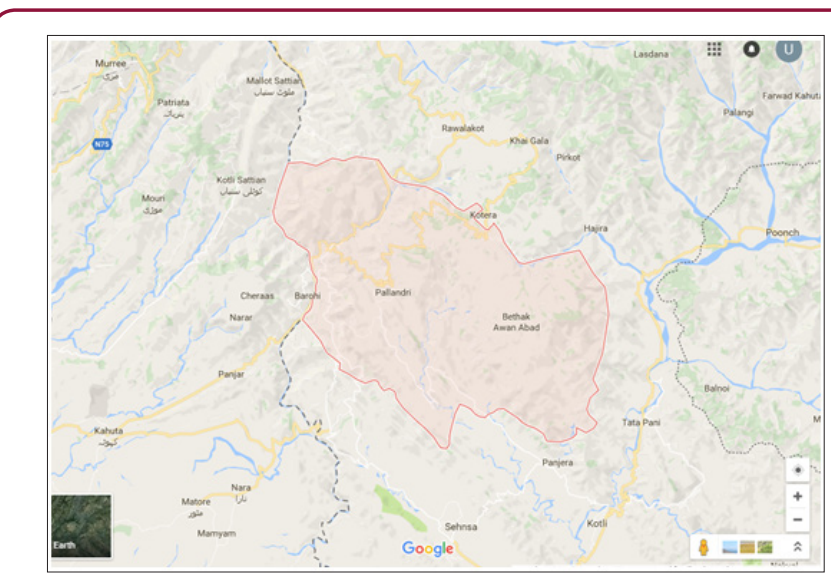

Figure 2:

\section{Discussion}

In present survey, the ethno botanical importance of the plants inhabiting Devi Galli is explored. Almost all the plant species were found important in one way or the other. Ajaib et al. [13 ] mentioned the medicinal importance of Berrberis lycium Royle, Jasminum humile $\mathrm{L}$ and Rubus elipticus Smith which were recorded in district Kotli, Azad Jammu and Kashmir. Ahmad et al. [13] also reported ethnobotanical uses of plants reported from district kotli including Achyranthus aspera and Adiantum venustum D. Don. Importance of these plants is also confirmed by Qureshi, Mehmood, Khan, Ishtiaq, Amjad. The need of the hour is to document and preserve the traditional knowledge about the medicinal uses of different plants as the new people are giving more importance to allelopathic medicines and the traditional knowledge is only confined to old people.

\section{Conclusion}

The current investigation discloses that indigenous knowledge is limited to native values, so this valuable treasure will be surely lost by any change in traditional culture. Ethno botanically important plants which are valuable global resources are threatened by the loss of habitats and over exploitation. The principle reason of over exploitation is lack of knowledge about the importance of plants and suitable harvest time and practice. The Devi Galli (Sodhnuti) contains diverse vegetation due to variation in climatic conditions and altitude. The people of the area to a large extent fulfill their common requirements such as food, medicine, fodder or forage 
and timber from plants. People of the area are not much aware about the medicinal treasure present in there this is because of illiteracy. Ethno botanically important area should be replenished by reforestation, establishment of home botanical gardens, conservation of natural resources, minimizing over grazing and harvesting for various purposes.

\section{References}

1. Husain ZS, Malik RN, Javaid M, Bibi S (2008) Ethnobotanical properties and uses of medicinal plants of Morgha Biodiversity Park, Rawalpindi. Pakistan Journal of Botany 40(5): 1897-1911.

2. Mahmood A, Malik RN, Shinwari ZK, Mahmood A (2011) Ethnobotanical survey of plants from Neelum, Azad Jammu and Kashmir, Pakistan. Pakistan Journal of Botany 43: 105-110.

3. Alpuerto AF, Bangaysiso TA, Galang V, Maquiling L (2010) Taylor Level of awareness and extent of utilization of the ten medicinal plants approved by the department of health. Nursing Research Journal 2(1): 73-92.

4. Khatun A, Rashid H, Rahmatullah M (2011) Scientific validation of eight medicinal plants used in traditional medicinal systems of Malaysia: A Review. American-Eurasian Journal of Sustainable Agriculture 5(1): 6775 .

5. Haq I (1997) Antimicrobial agents in Islamic medicine. Hamdard Medicus 11(4): 496-499.

6. Uniyal SK, Singh KN, Jamwal P, Lal B (2006) Traditional use of medicinal plants among the tribal communities of Chhota Bhangal, Western Himalayas. Journal of Ethnobiology and Ethnomedicines 2(14): 1-14.
7. Awan MR, Ahmad S (1997) Ethnobotanical studies of Swat district (Pakistan), Biodiversity of Pakistan 4(3): 159-167.

8. Ishtiaq M, Mumtaz AS, Hussain T, Ghani A (2012) Medicinal plant diversity in the flora of Leepa Valley. African Journal of Biotechnology 11(13): 3087-3098.

9. Khan MR, Rafi MA, Nazir N, Khan MR, Khan IA et al. (2014) Biodiversity of butterflies from Poonch division of Azad Kashmir. Journal of Agricultural Technology 10(4): 885-898.

10. Khan MA, Khan MA, Hussain M, Mujtaba G (2014) Plant diversity and conservation status of Himalayan Region Poonch Valley Azad Kashmir (Pakistan). Pak J Pharm Sci 27(5): 1215-1239

11.Vitalini S, Iriti M, Puricelli C, Ciuchi D, Segale A et al. (2013) Traditional knowledge on medicinal and food plants used in Val San Giacomo (Sondrio, Italy) an alpine ethnobotanical study. Journal of Ethnopharmacology 145(2): 517-529.

12. Savikin K, dunic ZG, Menkovic N, Zivkovic J, Cujic N et al. (2013) Ethnobotanical study on traditional use of medicinal plants in south western Serbia, Zlatibor district. Journal of Ethnopharmacology 146(3): 803-810.

13. Ajaib M, Khan Z, Khan N, Wahab (2010) Ethnobotanical studies on useful shrubs of district kotli, azad jammu \& kashmir, pakistan. Pak J Bot 42(3): 1407-1415.

14. Ali SI, Qaiser M Flora (2011) Department of Botany, University of Karachi, Pakistan, pp. 194-218.

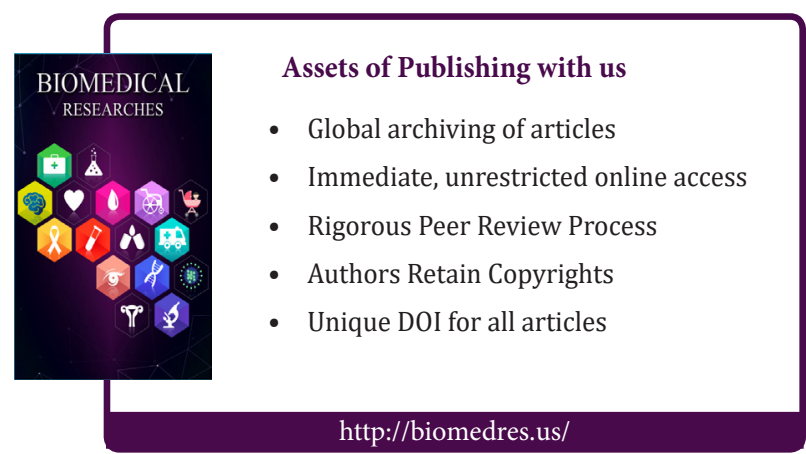

